\title{
Strategi Guru Kelas Dalam Mengatasi Kesulitan Belajar Akademik Siswa Dalam Pembelajaran Di Sekolah Dasar
}

\author{
Rini Dwi Susanti \\ IAIN Kudus, Jawa Tengah Indonesia \\ rinidwi@stainkudus.ac.id
}

\begin{abstract}
Abstrak
Guru kelas mempunyai peran dan tugas yang kompleks dalam pembelajaran. Dalam pelaksanaan pembelajaran sering sekali guru menemukan kesulitan-kesulitan belajar yang dialami siswa. Kesulitan belajar untuk siswa kelas satu di sekolah dasar lebih sering ditemukan pada kesulitan akademik yang meliputi kesulitan belajar menulis, kesulitan belajar membaca dan kesulitan belajar berhitung. Kesulitan belajar tersebut dapat diagnosis dengan mengidentifikasi kasus, mengidentifikasi masalah dan mengidentifikasi penyebab kesulitan belajar. Kesulitan belajar akademik siswa di kelas satu sekolah dasar ini dapat diantisipasi dengan pembiasaan yang continue sehingga permasalahan tersebut dapat diselesaikan secara bertahap.

Kata kunci: Guru kelas, kesulitan belajar akademik.
\end{abstract}

\begin{abstract}
Class teachers have complex roles and tasks in learning. In the implementation of learning, the teacher often finds learning difficulties experienced by students. Learning difficulties for first-grade students in elementary school are more often found in academic difficulties that include difficulty learning to write, difficulty learning to read and difficulty learning to count. Learning difficulties can be diagnosed by identifying cases, identifying problems and identifying causes of learning difficulties. Academic learning difficulties for students in the first grade of elementary school can be anticipated with continuous habituation so that these problems can be resolved gradually.
\end{abstract}


Keywords: Class teacher, academic learning difficulties.

\section{A. Pendahuluan}

Di sekolah banyak dijumpai berbagai keragaman karakter berikut juga dengan keragaman potensi yang dimiliki oleh setiap siswa. Dalam pelaksanaan pembelajaran guru terkadang guru kurang memahami perbedaan karakter dan potensi yang dimiliki oleh siswa, sehingga perlakuan antar satu siswa dengan siswa lainnya cenderung sama. Di lembaga sekolah banyak ditemukan beberapa siswa yang cenderung cepat dalam menangkap dan memahami pelajaran, ada juga yang lambat dalam memahami pelajaran dengan materi pelajaran yang sama. Perlakuan Guru kepada siswa cenderung hanya mendasarkan pada kondisi rata-rata siswa, sedangkan setiap siswa yang mempunyai cara belajar yang cepat dan lambat terabaikan. Kondisi yang demikian jika tidak disadari oleh guru maka akan berdampak buruk pada perkembangan potensi siswa.

Guru memiliki peran yang kompleks dalam pelaksanaan pembelajaran. Kompleksitas perannya Menurut Adam dan Becey dalam Basic principles of student teaching, tugas guru antara lain guru sebagai pengajar, pemimpin kelas, pembimbing, pengatur, pengatur lingkungan, partisipan, ekspeditor, perencana, supervisor, motivator dan konselor (http://semnasfis.unimed.ac.id)

Dalam pandangan lain tugas dan peran guru adalah mendorong, membimbing, dan memberi fasilitas belajar bagi pembelajar untuk mencapai tujuan. Guru mempunyai tanggungjawab untuk melihat segala sesuatu yang terjadi dalam kelas dalam rangka membantu proses perkembangan siswa. (Iskandarwassid\& Dadang Sunendar, 2013: 158).

Dalam pelaksanaan pembelajaran guru selalu dihadapkan pada persoalan-persoalan yang berkaitan dengan siswa, perilaku siswa, hasil belajar siswa dan lain-lain. Tentunya di sini guru harus memainkan peran yang kompleks untuk mengatasi berbagai problem yang dihadapi siswa maupun guru itu sendiri. Tidak setiap sekolah memiliki guru bimbingan dan koseling, sehingga dalam mengatasi persoalan pembelajaran guru harus mampu melaksanakan tugasnya sebagai konselor. Di lembaga pendidikan dasar yaitu sekolah SD maka yang berpelan adalah guru kelas. 


\section{Strategi Guru Kelas Dalam Mengatasi Kesulitan Belajar ...}

Urgensi bimbingan dan konseling di sekolah sangat diperlukan, sebagaimana yang diungkapkan oleh Koestoer Partowisastro sebagaimana yang dikutip oleh Imam Musbikin bahwa setidaknya disebabkan oleh factor sebagai beriku: 1) sekolah merupakan lingkungan hidup kedua sesudah rumah, dimana anak kurang lebih enam jam hidupnya berada di sekolah. 2) para siswa yang usianya relative muda sangat membutuhkan bimbingan baik dalam memahami keadaan dirinya, mengarahkan dan mengatasi berbagai kesulitan. (Imam Musbikin, 2010: 184-185)

Baerbagai kesulitan belajar dalam proses pembelajaran tentunya menjadi kendala dalam pelaksanaan pembelajaran. Kesulitan belajar adalah masalah yang dihadapi siswa khususnya dalam belajar. Bentuk-bentuk masalah belajar misalnya susah konsentrasi, kebiasaan belajar yang buruk, sukar menangkap pelajaran, mudah lupa dan sebagainya. (Elfi Mu'awanah\& Rifa Hidayah, 2012: 74). Dari sekian problem pembelajaran yang dihadapi siswa ataupun guru tentunya tidak dapat menyelesaikan dengan mudah. Oleh karena itu guru sebagai penanggungjawab pembelajaran harus mampu menyiapkan strategi-strategi tertentu untuk mengatasi problem tersebut.

Dalam mengelola kesulitan belajar siswa di sekolah dasar tentunya guru kelas harus memahami karakteristik siswa. Siswa pada masa usia sekolah dasar disebut dengan masa intelektual. ( Iskandarwassid \& Dadang sunndar, 2008, 141) Disebut dengan demikian karena siswa sekolah dasar pada umumnya memiliki keterbukaan dan keinginan untuk mendapat pengetahuan dan pengalaman. Pada tahap perkembangan siswa usia sekolah dasar merupakan suatu masa dimana siswa tersebut mempersiapkan diri untuk melangsungkan perkembangan hidupnya kelak. Maka guru sebagai pihak yang paling dekat dalam proses interaksi edukatif, maka perlu melakukan pembinaan agar siswa dapat melakukan tugas-tugas perkembangannya dengan baik. Selain itu guru juga harus mengembangkan keterampilan dasar kognitif: membaca menulis dan berhitung dan keterampilan sosial. Maka dalam tulisan ini akan dibahas tentang strategi guru kelas di sekolah dasar dalam mengatasi kesulitan belajar akademik siswa. 


\section{B. Pembahasan}

\section{Kompetensi Guru dalam Pembelajaran}

Kompetensi guru adalah kemampuan seorang guru dalam melaksanakan kewajiban-kewajiban secara bertanggung jawab dan layak. Hal ini berkaitan dengan profesionalisme guru yang kompeten (berkemampuan). Dengan demikian kompetensi profesionalisme guru dapat diartikan sebagai kemampuan dan kewenangan guru dalam menjalankan profesi keguruannya dengan kemampuan tinggi. Dengan kata lain kompetensi adalah pemilikan, penguasaan, ketrampilan dan kemampuan yang dituntut oleh jabatan seseorang.

Guru memegang peran penting dalam aktualisasi pembelajaran. Kompetensi profesional guru merupakan suatu keharusan dalam mewujudkan sekolah berbasis pengetahuan, pemahaman pembelajaran, kurikulum, dan perkembangan manusia termasuk gaya belajar siswa. Guru dengan kompetensi profesional akan menerapkan pola pembelajaran yang cenderung interaktif ada proses timbale balik antara guru dan siswa.

Keberhasilan guru yang profesional memiliki kompetensi yang cukup memadai. Menurut Depdikbud seperti yang dikutip oleh khoirunisa dalam (http://semnasfis.unimed.ac.id) kompetensi yang harus dimiliki seorang guru adalah : (1) Kompetensi Profesional, guru harus memiliki pengetahuan yang luas dari subject matter (bidang studi) yang akan diajarkan serta penguasaan metodologi dalam arti memiliki konsep teoritis mampu memilih metode dalam proses belajar mengajar; (2) Kompetensi Personal, artinya sikap kepribadian yang mantap sehingga mampu menjadi sumber intensifikasi bagi subjek. Artinya bahwa guru memiliki kepribadian yang pantas diteladani, yaitu "Ing Ngarsa Sung Tulada, Ing Madya Mangun Karsa. Tut Wuri Handayani"; (3) Kompetensi Sosial, artinya guru harus mampu menunjukkan dan berinteraksi sosial, baik dengan murid-muridnya maupun dengan sesama guru dan kepala sekolah, bahkan dengan masyarakat luas; (4) Kompetensi Peadagodik untuk melakukan pelajaran yang sebaik-baiknya yang berarti mengutamakan nilai-nilai sosial dari nilai material. 


\section{Urgensi Peran Guru Kelas dalam Pembelajaran di Sekolah Dasar}

Guru sebagai pelaku utama dalam penerapan program pendidikan di sekolah memiliki peran yang sangat penting dalam mencapai tujuan pendidikan yang diharapkan. Dalam proses belajar mengajar, guru mempunyai tugas untuk mendorong, membimbing, dan memberi fasilitas belajar bagi murid-murid untuk mencapai tujuan. Mengingat peranannya yang begitu penting, maka guru dituntut untuk memiliki pemahaman dan kemampuan secara komprehensif tentang kompetensinya sebagai pendidik.

Guru merupakan komponen paling menentukan dalam sistem pendidikan secara keseluruhan, seperti yang di ungkapkan oleh Brand dalam Educational Leadership menyatakan bahwa hampir semua usaha reformasi pendidikan seperti pembaharuan kurikulum dan metode pembelajaran, semua bergantung kepada guru.

Menurut Abu Ahmadi dan Widodo Supriyono,(1991) peran guru dalam proses belajar berpust pada : (1) Mendidik anak dengan memberikan pengarahan dan motivasi untuk mencapai tujuan, baik tujuan jangka pendek maupun tujuan jangka panjang; (2) Memberi fasilitas, media, pengalaman belajar yang memadai; (3) Membantu mengembangkan aspek-aspek kepribadian siswa, seperti sikap, nilainilai, dan penyesuaian diri. Jadi dapat dipahami bahwa peran guru di dalam kegiatan interaksi di kelas tidak dapat tergantikan.

Penyampaian materi pelajaran merupakan sebagai suatu proses yang dinamis dalam segala fase dan proses perkembangan siswa. Menurut Iskandarwassid dan Dadang Sunendar (2013:158) bahwa tugas guru berpusat pada usaha; 1) mendidik dengan titik berat pada memberikan arah dan motivasi pencapaian tujuan baik jangka panjang maupun pendek, 2)memberi fasilitas pencapaian tujuan melalui pengalaman belajar, 3) Membantu memperkenalkan aspek-aspek pribadi seperti sikap, nilai-nilai dan penyesuaian diri.

Di sekolah dasar guru yang bertanggung jawab dalam pelaksanaan pembelajaran dan interaksi di kelas adalah guru kelas. Guru kelas memiliki fungsi dan peran seperti guru yang lainnya di 
sekolah. Guru kelas bertugas untuk mengembangkan diri dan mengoptimalkan bakat dan minat siswa.

Dalam proses edukatif guru harus komunikatif dalam mejalankan perannya sebagai komunikator. Menurut Prey Ketz dalam sardiman (2011: 143) bahwa guru sebagai komunikator, sahabat yang dapat memberikan nasehat-nasehat, motivator sebagi pemberi motivasi dan dorongan, pembimbing dalam pengembangan sikap dan perilaku niali-nilai orang yang menguasai bahan yang diajarkan.

Ada beberapa hal yang pelu dilakukan guru sebagai motivator bagi siswa dalam pembelajaran yaitu: (1) memerimotivasi kepada siswa untuk belajar, (2) memberi penjelasan kepada siswa tentang tugas akhir dalam pembelajaran, (3) memberi ganjaran atas prestasi yang diraih siswa, dan (4) membentuk kebiasaan belajar yang baik. Jadi guru harus senantiasa memberikan motivasi kepada siswa untuk membuat revolusi dalam belajar sehingga siswa selalu berupaya untuk meningkatkan kualitas belajarnya. Karena pada hakikatnya guru adalah orang tua kedua di lembaga sekolah.

Guru juga harus dapat memainkan perannya sebagai orang yang senantiasa memberikan solusi bagi siswa atas persoalanpersoalan yang dihadapi. Peran guru sebagai konselor salau dibutuhkan untuk mengurai semua persoalan itu. Menurut Oemar Hamalik (2009: 34) Tugas guru sebagai konselor diantaranya adalah: a) mengumpulkan data tentang siswa, b) mengamati tingkah laku siswa dalam situasi sehari-hari, c)mengenal para siswa yang membutuhkan bantuan khusus, d) mengadakan pertemuan dengan orang tua siswa untuk memperoleh saling perhatian tentan pendidikan anak, e) bekerjasama dengan masyarakat dan lembaga lainnya untuk membantu memecahkan masalah siswa, f) membuat catatan pribadi g) menyelenggarakan bimbingan kelompok atau individu, h) menyusun program bimbingan sekolah i) meneliti kemajuan siswa,

Tugas bimbingan yang diadakan di sekolah bertujuan untuk: 1) mengatasi kesulitan dalam belajar, 2) mengatasi terjadinya kebiasaan yang tidak baik, 3) mengatasi kesulitan yang berhubungan dengan kesehatan jasmani, 4) mengatasi kesulitan yang berkaitan dengan kelanjutan studi, 5) mengatasi kesulitan yang berhubungan 


\section{Strategi Guru Kelas Dalam Mengatasi Kesulitan Belajar ...}

dengan perencanaan dan pemilihan jenis pekerjaan setelah tamat, 6) mengatasi kesulitan yang berhubungan dengan masalah sosio emosional, 7)

\section{Karakteristik siswa sekolah dasar}

Pada masa usia sekolah dasar siswa diharapkan dpat memperoleh pengetahuan dasar yang dipandang penting untuk mempersipkan dan menyesuaikan diri untuk tahap kehidupan selanjutnya. Anak usia sekolah dasar diharapkan memiliki keterampilan diantaranya,; a) keterampilan membantu diri sendiri yaitu anak mampu menyesuaikan dirimasalahannya sendiri dengan lingkungannya dan dapat menyelesaikan permasalahannya. b) keterampilan sosial, yaitu mampu bersosialisasi dengan teman sebaya dan orang yang lebih tua dengan baik. c) keterampilan sekolah, yaitu mampu bersekolah, mengikuti dan menyerap pelajaran dan d) keterampilan bermain yaitu mampu bermain-main sesuai tingkat usianya. Masa usia sekolah dasar disebut masa intelektual karena ketrbukaan dan keinginan anak untuk mendapat pengetahuan dan pengalaman.

Tugas perkembangan anak usia sekolah dasar merupakan suatu masa dimana dirinya dipersiapkan untuk melangsungkan perkembangan hidupnya kelak. Tugas guru adalah untuk mengembangkan keterampilan dasar dalam membaca, menulis dan berhitung dan mengembangkan sikap-sikap terhadap kelompok dan lembaga sosial.

Karakteristik siswa sekolah dasar dapat dilihat perkembagannya dari berbagai aspek, diantaranya (Iskandar wassid\& Dadang S, 2008:143-145):

a) Perkembangan fisik, secara fisik perkembangan pesat baik perkembangan fisiknya maupun mentalnya.

b) Perkembagan emosi, pada tahap ini anak usia sekolah dasar (611) muai menyadari keberadaannya bahwa dia mampu menyatakan dorongan dan emosinya dengan pertimbangan lingkungannya

c) Perkembangan mental intelektual, yaitu anak memasuki tahap perkembangan kognitif operasional kongkrit, dimana anak mulai 
belajar menghubungkan konsep-konsep baru dengan konsep lama.

d) Perkembangan sosial, yaitu anak tampak berkeinginan untuk berkelompok dan cenderung mengikuti nilai-nilai kelompok.

e) Perkembangan moral, yaitu anak sudah mampu membedakan nilai baik dan buruk sesuai dengan situasi dan kondisi

f) Perkembangan kepribadian memasuki sekolah dasar anak-anak mapu mengelola idelisme dirinya dengan berpatokan pada lingkungan dan orang-orang disekitarnya.

Dengan karekteristik siswa sekolah dasar berdasarkan tugas perkembanganya, maka guru kelas akan lebih nudah dalam mengenali dan menganalisis problem-problem yang dihadapi siswa, khusunya yang berkaitan dengan pembelajaran. Pemahaman terhadap karakteristik siswa menjadi dasar bagi guru dalam memperlakukan siswa sesuai dengan kebutuhannya.

\section{Kesulitan Belajar Siswa}

Siswa yang kesulitan belajar adalah siswa yang secara nyata mengalami kesulitan dalam tugas-tugas akademik baik secara khusus dan umum. Kesulitan tersebut disebabkan oleh adanya disfungsi neorologis, proses psikologis dasar maupun sebab-sebab lain sehingga prestasi belajarnya rendah dan siswa tersebut beresiko tinggi gagal dalam belajar. (Najib Sulhan, 2006: 33)

Menurunnya prestasi siswa belum tentu disebabkan oleh rendahnya potensi dasarnya, tapi ada kemungkinan lain. Salah satu faktor kegagalannya diantaranya yaitu guru belum memahami cara belajar siswa, siwa belum mengerti cara belajarnya. Selain itu faktor yang lain adalah kesehatan, motivasi diri, kondisi sekolah, kondisi rumah, dan lain-lain.

Ketidak berhasilan dalam proses pembelajaran untuk mencapai ketuntasan materi tidak dapat dilihat dari satu factor saja, namun ada banyak factor yang mempengaruhinya, diantaranya adalah siswa yang belajar, jenis kesulitan yang dihadapai, dan aktivitas dalam proses pembelajaran. Yang tepenting dalam mendiagnosa kesulitan belajar untuk menemukan jenis kesulitan belajara siswa dan cara mengatasinya agar proses pembelajaran berjan dengan baik. 


\section{Strategi Guru Kelas Dalam Mengatasi Kesulitan Belajar ...}

Menurut Munir Yusuf dalam Najib Sulhan (2006:33-34) kesulitan belajar siswa pada umumnya tidak hanya satu jenis saja. Hal ini karena siswa mengalami kesulitan pada salah satu dari kemampuan akademik terutama, membaca, menulis dan berhitung. Jika tidak segera diatasi maka siswa akan kesulitan dalam bidang lain, karena ketiga kemampuan tersebut adalah dasar untuk mempelajari pengetahuan.

Kesulitan belajar dikelompokkan dalam menjadi dua jenis; Pertama, kesulitan praakademik yang meliputi: 1) ganggunan motorik dan persepsi yaitu gangguan intelengensia auditori memori, sedangkan gangguan persepsi adalah mencakup penglihatan (visual). 2) gangguan belajar kognitif yaitu mencakup berbagai aspek struktur intelektual, 3) gangguan belajar pekembangan bahasa (disfasia) yaitu ketidakmampan dalam menggunakan symbol linguistic dalam rangka berkomunikasi secara verbal dan 4) Gangguan penyesuaian presepsi sosial (Ibid, 34-34)., Kedua, Kesulitan belajar akademik yang meliputi kesulitan dalam membaca, menulis dan berhitung.

Kesulitan belajar akademik ini selalu dihadapi oleh siswa terutama bagi siswa di sekolah dasar khusunya pada siswa di kelas 1 yang nota benenya adalah siswa yang masih penyesuaian dengan lingkungan baru di sekolahnya. Dan hal inilah yang kemudian siswa sering sekali mendapat kesulitan dalam belajar di kelas yang berkaitan dengan materi-materi dasar seperti, munis membaca dan berhitung (CALISTUNG).

Proses belajar di kelas adalah kegiatan yang sangat kompleks, siswa sendirilah yang menentukan terjadi atau tidaknya perbuatan belajar. Dalam proses belajar di kelas siswa menghadapi persoalan-persoalan baik secara internal atau eksternal. Menurut Dimyati dan Mulyono (1994; 228-235) bahwa factor internal yang berpengaruh terhadap belajar siswa di kelas adalah : (a) sikap terhadap belajar, (b) motivasi, (c) konsentrasi (d) mengolah bahan belajar, (e) menyimpan perolehan hasil belajar, (f) menggai hasil belajar yang tersimpan, $(\mathrm{g})$ kemampuan berprestasi, $(\mathrm{h})$ rasa percaya diri siswa, (i) intelegensi dan keberhasilan belajar kebiasaan belajar (j) dan (k) cita-cita siswa. 
Adapun factor eksternal dipengaruhi oleh hal-hal sebagai berikut: (1) guru sebagai Pembina siswa dalam belajar, (2) sarana dan prasarana pembelajaran, (3) kebijakan penilaian (4) lingkungan sosial siswa dan (5) kurikulum. Oleh karena itu dari beberapa factor tersebut baik internal maupun eksternal maka jika pembelajaran tidak dikelola dengan baik maka tingkat keberhasilan belajar siswa tidak bisa maksimal.

\section{Jenis-Jenis Kesulitan Akademik di sekolah Dasar}

Ada berberapa kesulitan belajar siswa yang sering ditumukan dalam proses belajar siswa di kelas awal, diantaranya (Ibid: 35-37)

\section{a. Kesulitan Membaca (disleksia)}

Kesulitan Membaca (disleksia) yaitu kesulitan belajar tipe ini meliputi dua tipe kesulitan auditoris dan disleksia visual. disleksia Auditoris memiliki gejala sebagai berikut:

1. Kesulitan dalam diskriminasi auditoris dan persepsi senhingga mengalami kesulitan dalam analisis fonetik.

2. Kesulitan analisis dan sintesis auditoris

3. Kesulitan auditoris bunyi atau kata

Kesulitan disleksia visual meliputi; tendensi terbalik, kesulitan diskriminasi, kesulitan dalam mengikuti dan mengingat urutan visual, memori visual terganggu, kecepatan persepsi lambat, kesulitan analisis dan sintesis visual, hasil tes buruk. Sedangkan untuk siswa yng mengalami kesulitan belajar memiliki cirri-ciri; tidak lancar membaca, sering terjadi kesalahan dalam membaca, kemampuan memahami isi bacaan rendah dan kesulitan dalam membedakan membedakan huruf yang mirip.

a. Kesulitan belajar menulis (disgrafia), Adapun ciri-ciri siswa yang mengalami disgrafia adalah ; Tulisan terlalu jelek, tidak terbaca,sering terlambat dalam menyalin tulisan, tulisan banyak salah, sulit menulis lurus pada kertas yang tidak bergaris, dan menulis huruf tidak dengan kaidah bahasa.

b. Kesulitan belajar berhitung, (Diskalkula), adapun siswa yang memiliki gangguan ini memiliki cirri-ciri sebagai berikut: sulit membedakan tanda-tanda dalam berhitung, sulit mengorasikan bilangan, sering membedakan angka mirip, dan sulit membedakan bangunan-bangunan geometri 


\section{Strategi Guru Kelas Dalam Mengatasi Kesulitan Belajar ...}

Menurut Sugiyanto dalam( www.uny.ac.id :117) bahwa beberapa ciri yang merupakan pernyataan manifestasi manifestasi kesulitan belajar siswa antara lain:

1. Menunjukkan hasil belajar yang rendah di bawah nilai rata-rata yang dicapai oleh kelompoknya atau dibawah potensi yang dimiliki

2. Hasil yang dicapai tidak seimbang dengan usaha yang dicapainya.

3. Lambat dalam melaksanakan tugas-tugas belajar

4. Menunjukkan sikap-sikap yang tidak wajar, seperti acuh tak acuh, menentang, pura-pura, dusta dan sebagainya.

5. Menunjukkan tingkah laku yang berkelainan seperti membolos, datang terlambat, tidak mengerjakan pekerjaan rumah, menggangu did lam kelas atau diluar kelas, tidak mencatat pelajaran, menasingkan diri, tersisihkan dan tidak mau bekerjasama dengan orang lain.

6. Menunjukkan gejala emosional yang kurang wajar

Demikianlah dampak yang ditimbulkan akibat adanya kesulitan belajar siswa khusunya kesulitan akademiknya. Hal ini perlu penanganan khusus dari guru kelas dalam interaksi edukatif di kelas.

Kesulitan belajar berdampak pada kegagalan belajar siswa secara simultan. Mengatasi persoalan tersebut guru kelas perlu melakukan identifikasi dari persoalan tersebut. Menurut Burton dalam Sugiyanto (www. uny.ac.id : 117-118) bahwa siswa dikatakan gagal dalam belajar jika : 1) dalam batas waktu tertentu siswa tidak mencapai ukuran tingkat keberhasilan, 2) tidak dapat mencapai prestasi yang semestinya 3) tidak dapat mewujudkan tugas-tugas perkembangan, 4) tidak berhasil mencapai tingkat penguasaan yang diperlukan sebagai prasyarat bagi kelanjutan pada tingkat pelajaran selanjutnya.

\section{Strategi dalam mendiagnosis kesulitan belajar akademik siswa}

Tugas dan tanggung jawab lembaga pendidikan sekolah adalah memberikan dan menciptkan kesempatan yang luas kepad 
siswa untuk mengasah potensi, bakat yang dimilikinya secara optimal. Problematika yang dihadapi oleh sekolah adalah pencapaian prestasi siswa yang tidak sesuai dengan harapan. Berbicara tentang prestasi belajar tentunya hal ini dikatkan dengan keberhasilan guru dalam mengantarkan siswanya mencapai prestasi yang gemilang melalui pelaksanaan pembelajaran yang optimal.

Optimalisasi pembelajaran menjadi tugas pokok guru kelas dalam mengantarkan siswanya untuk mencapai prestasi yang baik. Pada kenyataannya proses belajar memang berliku. Guru sering dihadapkan pada persoalan yang berkaitan dengan siswa. Kesulitan dalam siswa sekolah dasar dalam beradaptasi dengan lingkungan belajarnya menjadi sumber kegagalan guru dalam pencapaian prestasi.

Terkadang guru terlalu berharap pada hasil prestasi siswa yang tinggi namun dalam kenyatanya justru mengecewakan. Oleh karena itu guru harus mengenali, mengevaluasi dan mengidentifikasi penyebab terjadi penurunan hasil belajar siswa. guru perlu melakukan identifikasi potensi siswa ditelusuri dari prestasi sebelumnya dengan melakukan observasi atau tes psikologi. Apabila dari hasil observasi dan identifikasi, ada indikasi bahwa siswa mengalami kesulitan belajar maka perlu ada tindakan segera untuk mengatasinya. Bantuan akan efektif dilakukukan jika guru secara teliti mampu mengidentifikasi kesulitan siswa ditinjau dari sfita kesulitannya, faktor penyebabnya dan cara mengatasi yang relevan dengan faktor penyebabnya.

Beberapa langkah yang dilakukan untuk menidentifikasi dan menyelesaikan kesulitan belajar akademik siswa di sekolah dasar dalam pembelajaran:

1. Mengidentifikasi kasus yaitu dengan menandai siswa yang mengalami kesulitan belajar secara acak dilihat dari tingkat prestasinya adapun teknik yang dilakukan adalah meneliti hasil ujian semester atau ujian akhir yang tercantum dalam laoran nilai dengan membandingkan nilai rata-rata kelompok sesuai criteria yang ditentukan atau berdasarkan KKM (Kriterian Ketuntasan Minimal) yang sudah ditetapkan. Mengobservasi kegiatan belajar siswa dengan mengamati kemungkinan kesulitan belajar yang dialami siswa 


\section{Strategi Guru Kelas Dalam Mengatasi Kesulitan Belajar ...}

2. Mengidentifikasi masalah, hal ini dapat dilakukan dengan melibatkan orang tua. pada tindakan ini diterapkan pada mata pelajaran yang sesuai. Karena kesulitan belajar akademik lebih difokuskan pada materi membaca,menulis dan berhitung maka bisa diterapkan untuk mata pelajaran bahasa Indonesia dan matematika dasar untuk kelas 1. Adapun cara yang dilakukan adalah sebagai berikut:

a. Tes diagnostik diterapkan untuk mata pelajaran bahasa Indonesia di kelas satu. Tujuannya adalah untuk menemukan kesulitan membaca dan menulis siswa kelas 1sehingga ditemukan karakteristik kesulitan yang dialami siswa

b. Bila langkah pertama belum ada dapat dilakukan dengan menggunakan hasil ujian yang telah dilakukan jika ujian tersebut memiliki validitas yang tinggi sehingga hasil tes tersebut dapat untuk menganalisis kesulitan siswa

c. Dapat dilakukan dengan memeriksa buku atau pekerjaan siswa (portofolio) untuk menganalisis kesulitan belajar siswa

3. Menidentifikasi factor penyebab kesulitan belajar

Ada dua faktor dalam penyebab kesulitan belajar, yaitu factor internal yang meliputi ; a) kelemahan fisik, syaraf, cacat dan lain-lain, b) kelemahan mental; kecerdasan, intelegensia, c) gangguan yang bersifat emosional, d) sikap yang salah dalam mempelajari materi pelajaran, e) belum meiliki pengetahuan dan kecakapan dasar yang dibutuhkan untuk memahami mata pelajaran. Sedangkan untuk faktor eksternalnya adalah: a) situasi atau proses belajar yang tidak memberikan rangsangan bagi siswa untuk aktif dan antisipatif dalam pembelajaran, b) kurikulumyang tidak fleksibel c) beban belajar yang terlalu berat, d) metode pembeajaran yang tidak menarik, e) minimnya alat atau sumber belajar, f) situasi rumah yang tidak kondusif

Dengan teknik pengidentifikasian yang berkaitan dengan kesulitan belajar siswa, maka untuk langkah selanjutnya bagi guru akan lebih mudah. Guru dapat mengelompokkan siswa dengan tingkat kesulitasn yang beragam. Tentunya guru dapat mengelompokkan secara homogen sehingga penyelesaian untuk mengatasi kesulitan belajar yang dihadapi siswa mudah untuk diselesaikan. 
Misalnya untuk siswa dengan tingkat kesulitan belajar akademik dari aspek disleksia visual dengan ciri tendensi terbalik seperti $b$ dibaca $d, p$ dibaca $g$, u dibaca $n$ dan $m$ dibaca $w$, maka guru dapat memberikan tes bacaan. Tujuannya adalah membiasakan siswa untuk selalu melihat perbedaan-perbedaan huruf. Tugas guru kelas ini adalah selalu melakukan latihan yang berulang-ulang dengan tujuan siswa terbiasa melihat perbedaan, sehingga mudah untuk mengidentifikasi kesulitan itu. guru selalu mengamati kegiatan dan pekerjaan siswa. Sehingga guru dapat menemukan kesulitankesulitan yang dihadapi siswa. guru juga dapat mengetahui kesalahan-kesalahan yang dilakukan siswa, dan hal ini sebagai landasan untuk memperbaiki kesalahan itu.

Dalam kegiatan ini bersifat pengembangan (developmental) dengan demikian siswa dapat mengetahui kekurangan dan kekeliruannya. Sehingga siswa akan berusaha untuk melakukan perbaikan secara kontinyu. Perubahan siswa ke arah positif dapat dilihat dari perkembangan siswa yang mengalami kemajuan secara bertahap. Oleh karena itu guru harus senantiasa memantau perkembangan belajar siswa terutama bagi siswa yang mengalami kesulitan belajar.

Biasanya untuk tingkat kesulitan belajar akademik yang berkaitan dengan membaca dan menulis di kelas 1 sekolah dasar dapat diantisipasi dengan latihan yang terus menerus sehingga siswa terbiasa melihat dan mengamati bentuk huruf dan tulisan, Karena untuk kesulitan membaca di kelas satu dapat diatasi melalui pembiasaan.

\section{Simpulan}

Guru memiliki peran yang komples dalam memberikan solusi bagi siswa atas persoalan-persoalan yang dihadapi dalam prmbelajaran. Peran guru sebagai konselor salau dibutuhkan untuk mengurai semua persoalan itu. problematika pembelajaran yang sering dihadapi guru adalah menyelasaikan persoalan yang berkaitan dengan kesulitan belajar siswa. Kesulitan belajar siswa meliputi kesulita praakademik dan kesulitan akademik. Dalam proses pembelajaran guru harus memahami karakteristik siswa untuk menganalisi kesulitan belajar yang dihadapi siswa. di sekolah dasar 


\section{Strategi Guru Kelas Dalam Mengatasi Kesulitan Belajar ...}

kelas satu siswa sering mengalami kesulitan belajar akademik yang meliputi membaca, menulis dan berhitung. Hal ini disebabkan oleh latar belakang siswa sebelum masuk pendidikan dasar yang belum memiliki kemampuan dasar tersebut.

Untuk mengantisipasi dan menyelesaikan persoalan tersebut guru perlu memiliki strategi khusus yaitu dengan melakukan identifikasi kasus, identifikasi masalah dan identifikasi factor penyebab kesulitan belajar tersebut. setelah melakukan indentifikasi-identifikasi tersebut, maka guru dapat menerapkan pembiasan-pembiasan membaca, menulis dan berhitung secara kontiue unuk mengurangi kesulitan tersebut, sehingga kesulitan belajar akademik itu dapat diselesaikan secara bertahap. 


\section{Rini Dwi Susanti}

\section{Daftar Referensi}

Abu Ahmadi dan Widodo Supriyono. Psikologi Belajar. Jakarta: Rineka Cipta. 1991

Dimyati dan Mujiyono, Belajar dan Pembelajaran, Jakarta: Direktorat Jendral Pendidikan Tinggi Depdikbud, 1994

Elfi Mu'awanah\& Rifa Hidayah, Bimbingan Konseling Islami di Sekolah Dasar, Jakarta: Bumi Aksara, 2012

Imam Musbikin, Guru Yang Menakjubkan, Jogjakarta: Buku Biru, 2010 Iskandarwassid \& Dadang Suhendar, Strategi Pembelajaran Bahasa, Bandung: Remaja Rosdakarya, 2013

Khoirunnisa, Peran Guru dalam Pembelajaran dalam Prosediing seminar Nasional Tahunan, Medan: Universitas Negeri Medan, 2017 dalam http://semnasfis.unimed.ac.id diakses tanggal 28 November 2018

Najib Sulhan, Pembangunan Karakter pada Anak Manajemen Pembelajaran Guru Menuju Sekolah Efektifi, Surabaya: SIC, 2006

Oemar Hamalik, Psikologi Belajar dan Mengajar, Bandung : PT Sinar Baru Algesindo, 2009

Sardiman, A.M., Interaksi dan Motivasi Belajar dan Mengajar, Jakarta: PT Grafindo Raja Persada, 2011 